\title{
Book Review: Democracy, Schooling and Political Education
}

\author{
İbrahim Hakkı Öztürk*
}

* Independent researcher, Ankara, Turkey. E-mail: ibra.ozturk@gmail.com

\section{Article Info}

Received: August 18, 2021

Revised: November 5, 2021

Accepted: December 20, 2021

\section{$10.46303 /$ repam.2021.7}

\section{How to cite}

Öztürk, i. H. (2021). Book Review:

Democracy, Schooling and Political

Education. Research in Educational Policy

and Management, 3(2), 73-77.

https://doi.org/10.46303/repam.2021.7

\section{Copyright license}

This is an Open Access article distributed under the terms of the Creative Commons Attribution 4.0 International license (CC BY 4.0).

\section{ABSTRACT}

This paper reviews the book Democracy, Schooling and Political Education, written by Colin Wringe (published in 2012 by Routledge, first ed. in 1984, 126 p.). Although, the book was written in the last quarter of the 20th century towards the end of the cold war period, it is highly up-to-date in terms of the topic it covers. Wringe's work addresses the teachers and other professionals in education, and also all who are interested in relationship between education and democracy, without a strong background in the field.

\section{KEYWORDS}

Book review; democracy; political education; schooling; equality; diversity. 


\section{BOOK REVIEW}

\section{Colin Wringe (2012, first ed. 1984). Democracy, Schooling and Political Education.}

\section{Routledge. 126 p.}

Rethinking the relationship between education and democracy has become an urgent issue in these "dangerous times" when democracy is in a state of profound crisis (Riddle \& Apple, 2019). The Freedom Hause's report, Freedom in the World 2021: Democracy under Siege (Repucci and Slipowitz, 2021), begins with these alarming observations about the state of democracy in the world:

As a lethal pandemic, economic and physical insecurity, and violent conflict ravaged the world in 2020, democracy's defenders sustained heavy new losses in their struggle against authoritarian foes, shifting the international balance in favor of tyranny. Incumbent leaders increasingly used force to crush opponents and settle scores, sometimes in the name of public health, while beleaguered activists-lacking effective international support-faced heavy jail sentences, torture, or murder in many settings.

According to the Report, since 2006, the countries that experienced deterioration in their political rights and civil liberties are more numerous than that experienced improvements, and 2020 was the " $15^{\text {th }}$ consecutive year of decline in global freedom" (Repucci and Slipowitz, 2021, p. 1-2).

Democracy, Schooling and Political Education (2012, first ed. 1984), written by Colin Wringe, has been published by Routledge as a part of "a collection of short, readable works which, besides being philosophically sound, will appeal to future and existing teachers without a previous knowledge of philosophy or philosophy of education" (p. ix). The book is suitable not only for teachers and other professionals in education, but also for all who are interested in relationship between education and democracy, without a strong background in the field. Even though the book was written in the last quarter of the 20th century, towards the end of the cold war period, it is highly up-to-date in terms of the topic it covers. Wringe's work is a very useful handbook for those who will make their first reading on the relationship between democracy and education.

The book is divided into eight chapters. The first chapter, Eucation and Society, serves as a general introduction to the topic:

Education is not simply the mindless passing on of a body of facts. Usually it is regarded as some kind of preparation for the future lives of pupils as members of their particular society. Consequently, both the beliefs and values and the information which educators 
are expected to transmit and give emphasis to will depend on what it is thought important for future citizens of that society to know. (p. 2)

Unlike the surgeon and the plumber, the teacher cannot simply 'get on with his job' and leave social and political considerations to others. Such considerations determine in part what his job is. [...] A teacher cannot restrict himself to the task of 'getting on with the task of teaching' without reference to the wider social and political context, for this context will have an important effect on what he has to teach and how he is able to teach it. If our society claims to be a democracy of some kind the education of its future citizens must necessarily be concerned with enabling them to live and function in such a society and come to some understanding of it. (p. 3-5)

In the second chapter, The Meanings of Democracy, the author introduces his readers to the concept of democracy. He underlines and analyses different views of democracy such as "liberal democracy", "corporate democracy", "representative democracy" and "participatory democracy", and distinguishes different ways in which the term democratic can be used. The author concluded that although there are different views of democracy, they "have at least one thing in common: that in some sense of the term the good of the people is supposed to be the prime purpose for which the state and other institutions exist" (p. 18).

In the third chapter, Justifying Democracy, Wringe focus on arguments in favor of liberal democracy: efficiency and equality of rights. "Democracy is not only morally preferable to dictatorship but also the more expedient way for a state to organise itself" (p. 20). Active involvement of the citizens in the political process, criticism and the possibility of alternative policies, more transparency of decision-making and implementation processes, and open and regular competition between ideas and political groups are factors that make democratic governments more effective. In democracy, "people have a right to be governed, or govern themselves" (p. 19). Equality of rights requires that nobody "should accept any arrangement for co-ordinating our collective affairs, that is, any system of government, that accords him less right to consideration or a less than equal degree of influence than others over what is to be done" ( $p$. 23).

By the fourth chapter, Indoctrination, Schooling and Reproduction, the author begins to deal with the relationship between democracy and education. According to Wringe, education is necessarily political, because it "is the process by which society renews itself and passes on its acquired knowledge and the values it regards as important" (p. 34). Wringe advocates a prodemocratic education and criticizes the view that sees democratic education as an political indoctrination in a negative sense. He outlines the difference between "democratic educator" and "anti-democratic indoctrinator". He states that; 
[..] liberal democracy is by no means an ideology like its various rivals. liberal democracy is by no means an ideology like its various rivals. On the contrary, whereas the hierarchies in both its religious and its secular alternatives must expend considerable energies in managing information and exerting various kinds of pressure in order to secure orthodoxy, democracy is unique in that it is supposed to thrive on free access to information and open discussion. (p. 35)

In the fifth chapter, Equality, Freedom and Diversity, Wringe argues that "anyone committed to democracy must remain suspicious of any proposal which will result in a significant section of the population receiving a special and recognisably superior form of education" ( $p$. 52). However, although he points out some negative social effects, he does not categorically reject private education.

In the sixth chapter, The Democratic Government of Education, the author advocates expanding the roles and freedoms of teachers in planning of education for a more democratic school administration. He emphasizes also the need for a greater cooperation between teachers and administrators for the achievement of a plurality of educational goals.

In the seventh chapter, Education and Democracy, Wringe discusses what the content of education should be in a democratic system. He argues that education should not be in a way that imposes a certain perspective or educational content:

To be committed to democracy is not to be committed to holding that particular policies or even a particular conception of the good should be pursued in the state as a whole. Rather it lays down, in a general way, limits to which the manner in which things are decided must conform. In much the same way, democracy makes few specific demands regarding the content of education, other than those of a general and procedural kind, such as that knowledge should be presented a something relevant to us all, and as something which, in principle, all can check and generate for themselves. (p. 87)

In the eighth and final chapter, Political Education in A Democracy, the author states that the concept of "political education" have a bad reputation as a result of their use in totalitarian regimes. At the same time, this is a contested issue. "What is and what is not political is itself a political issue. Consequently, there is no possibility of agreement as to what may legitimately be included in a political education syllabus" (p. 94). Addressing controversial political issues in school is a very sensitive matter. It risks being indoctrinatory. However, according to Wringe, "it is no solution simply to avoid such discussion in school altogether. To leave someone in a state of ignorance or error may be every bit as much a biased act as telling him something" (p. 94). In school, political issues must be taught openly and explicitly with the idea of objectivity. Wringe outlines that the content of political education is subject to on-going discussion and controversy and he don't propose a particular style of political education. 
The book includes a rather rich bibliography at the end, and the author provides also "Suggestions for Further Reading" for each chapter.

Wringe's book is suitable not only for teachers and other professionals in education, but also for all who are interested in relationship between education and democracy, without a strong background in the field. Even though the book was written in the last quarter of the 20th century, towards the end of the cold war period, it is highly up-to-date in terms of the topic it covers.

\section{REFERENCES}

Repucci, S. \& Slipowitz, A. (2021). Freedom in the World 2021: Democracy under Siege.

Freedom House. https://freedomhouse.org/sites/default/files/2021-

02/FIW2021 World 02252021 FINAL-web-upload.pdf

Riddle, S \& Apple, M. W. (2019). Education and democracy in dangerous times. In Riddle, S \& Apple, M. W. (Eds.) Re-imagining Education for Democracy. Routledge, (1-10). 